http://dx.doi.org/10.4314/jae.v15i1.5

\title{
Farmers' Awareness and Use of Automated Teller Machines (ATMs) in Selected Communities in Enugu North Senatorial Zone, Enugu State
}

\author{
Onovo, C. L. and Enwelu, I. A \\ Department of Agricultural Extension \\ University of Nigeria, Nsukka, Enugu State \\ Email:enwachonamin@yahoo.com
}

\begin{abstract}
The study determined farmers' awareness and use of automated teller machines (ATMs) in some selected communities in Enugu North Senatorial Zone of Enugu State. Interview schedule was used to collect data from a sample size of sixty (60) respondents using purposive selection. Percentage, frequency, and mean scores were used in analyzing data. Majority of the respondents were aware of bank account (95.02\%), withdrawal booklet (91.7\%) and ATM card (81.7) while few were aware of ATM function keys (41.7\%) and ATM cash dispenser (20.0\%). The main sources of information on ATMs were bank personnel (80.0\%), friends and neighbours (75.0\%), family members (73.3\%). Other sources were newspaper (43.3\%), schools (36.7\%) and extension workers (18.3\%). A greater percentage of farmers (55\%) indicated the use of ATM for cash withdrawals while other transactions included transfer of funds (16.7\%) and paying bills/fees/taxes (15.0\%). The serious constraints to the use of ATM included fraud $(M=1.65)$, charges on the use of ATM $(M=1.22)$ and network problems $(M=1.22)$. Perceived benefits of the use of ATM included time saving $(M=2.85)$, cash withdrawal $(M=2.70)$, easy access $(M=2.60)$ and greater efficiency $(M=2.45)$. The study recommends that public awareness should be created through workshops, seminars and conferences as well as mounting multiple security cameras and security guards to reduce fraud.
\end{abstract}

Key words: Awareness, use, benefit and importance of ATMs

\section{INTRODUCTION}

Electronic payment is relatively a new phenomenon in Nigeria. Most transactions in the country are done with cash. This is because cash remains the preferred medium for payment in the country. Cheques for many years have been the only option to cash in the economy. However, cheques have not been acceptable to merchants because of fraud and the resultant mistrust that they create. Incidence of bounced cheques was very high making merchants cautious in accepting them. This was also because of lack of an electronic means of 
verifying valid cheques (Naija Techguide, 2009). Part of the problem was also the poor interconnection of banks and a lack of an electronic cheque clearing system.

However, today banks now have branches interconnected together. The Central Bank of Nigeria (CBN) has also introduced interbank electronic cheque clearing system, which has greatly reduced the time it takes to redeem cheques. Despite these positive developments, the fate of paper cheques in the economy seems to have been sealed. For any payment system to be able to replace cash (or at least compete with it), it must win the trust of customers in the economy. For this to happen, there must be a way for farmers to verify the validity of their purchases. The payment solution must also be easily convertible to cash, since most farmers in Nigeria operate on subsistence basis. Also, they should be encouraged to put their money in banks.

This is where e-payment or e- transaction solutions come in. The solutions target most of the concerns of merchants, farmers, civil servants and more. However, despite its advantages, e-payment system has not gained much ground. Globally, according to Olatokun and Igbinedion (2009), automated teller machines (ATMs) have been adopted by banks. ATMs are set up to provide 24-hour service to bank customers, who cannot transact with banks in the same period of time (Ugwu, 2008). The machines can enable depositors to withdraw cash at more convenient times and places than during normal banking hours. This is the main essence of ATM for agricultural purposes because agricultural activities are time bound. This advantage should be maximized by assessing farmers' credit via ATMs. With ATM, it is a lot easier to withdraw money or check account balance. Naija Techguide (2009) posits that ATM is the most popular e-transaction in the country.

In Nigeria, ATM technology is becoming more common than it ever was and appears to be mainly provided by most banks in Nigeria (Fasan, 2007). Yet, wide spread adoption of ATM by customers particularly farmers is not clear, as it appears that people's perception of the technology is diverse, which in turn affects their decision to actually use it or not. Despite the rapid growth in the availability and use of ATMs, they remain a minor part of withdrawal of cash to farmers in their farming activities. Customers including merchants, farmers, and civil servants have been reluctant to switch from traditional methods of withdrawal to the use of ATMs despite claims of cost savings, convenience and greater efficiency.

The fact remains that banks are mostly located only in urban areas. This fact was buttressed by Okoye (1995) when he pointed out that more than $80 \%$ of Nigerians living in rural areas still had no access to banking facilities. To compound the situation, in many rural areas, income levels are so low that savings may not even be enough for transactions and precautionary purposes. In such a scenario, only large and medium scale farmers have the opportunity of patronizing the banks. However government rural banking programmes and other banking policies have made it possible for banks to be established in rural areas, some with ATM facilities. The slow acceptance of the ATM use by farmers might be traced partly to problems inherent in any attempt to make a major change in any 
system (banking sector). According to Chang and Cheung (2001), complexity also has significant relationship with intention to use ATMs.

It is also observed that banks still have many customers transacting with tellers within their doors and queues are still not a thing of the past inside banks. The patronage of ATMs is not well defined and even epileptic at best, as sometimes long queues are observed outside ATMs while at other times there are few or no customers (Olatokun and Igbinedion, 2009). And so, ignorance, poor banking culture, lack of trust, illiteracy and love for the status quo remain a great problem in the use of ATM and thus creates a gap between what is and what ought to be.

To bridge this gap, this study sought to ascertain farmers' awareness and use of ATMs in selected communities in Enugu North senatorial zone. Specifically, the study sought to: identify farmers' sources of information on ATMs; ascertain farmers' level of awareness of ATMs; ascertain farmers' level of use of ATMs; determine farmers' constraints in the use of ATMs; and ascertain farmers' perceived benefits from the use of ATMs.

\section{METHODOLOGY}

The study was carried out in Enugu North senatorial zone of Enugu State. Farmers that have bank accounts in the selected communities constituted the population of the study. Three local government areas (LGAs) (Nsukka, Udenu and Igbo-eze South) out of the seven LGAs in the zone were purposively selected due to the presence of banks in the LGAs. In Nsukka, Udenu and Igbo-eze south LGAs, Nsukka, Orba and Ovoko town communities were purposively selected due to the existence of banks with ATM facilities in the communities. Several visits were made to the bank in each community to interview customers who were farmers using interview schedule. At the end, twenty farmers were interviewed in each bank making a total sample size of sixty farmers.

A list of information sources was provided and respondents were asked to indicate their source of information. Information sources were measured as number of information sources through which each respondent got to know about ATM. The maximum number of information sources was 48 while the minimum was 6. Respondents' level of awareness of ATMs was measured as: not aware $=0$, aware $=1$. A set of questions requiring yes or no were evaluated and the index score of each respondent taken. The items whose index scores were $50 \%$ and above were rated as high awareness and those whose index score were below $50 \%$ were rated as low awareness. Respondents' level of use was similarly measured with index score of $50 \%$ and above as high level of use and scores below $50 \%$ as low level of use. Constraints on the use of ATMs were measured by rating on a 3- point Likert type scale of very serious $=2$, serious $=1$, not serious $=0$. The values were added up to three (3) and divided by 3 to give a mean score of 1 . Variables with mean score greater or equal to 1 were seen as serious constraints on the use of ATMs while mean scores less than 1 were seen as not serious. On the other hand, the perceived benefits of ATM use were measured by rating on a 4- point Likert type scale of very important $=3$, important $=2$, less important $=1$, not 
important $=0$. These values were added up to give 6 and divided by 4 to give a mean score of 1.5. Any mean score greater or equal to 1.5 was perceived as important and otherwise. Data collected were analyzed using percentage, frequency and mean scores.

\section{RESULTS AND DISCUSSION}

\section{Sources of information on the use of ATM}

Data in Table 1 show that the respondents got their information on ATM use from bank personnel $(80.0 \%)$, friends and neighbours $(75.0 \%)$, family members $(73.3 \%)$ radio $(61.7 \%)$ and television $(58.3 \%)$. Other sources were newspaper (43. $3 \%)$, schools (36. 7\%) and extension workers (18.3\%). The implication is that majority of the respondents got their information of ATM from the bank where the ATMs are usually located. According to a recent survey conducted by Intermarc Consulting Limited, it was revealed that ATM services provided by banks and nonfinancial institutions stood as the most popular e-business platform in Nigeria (Omankhanlen, 2007).

Surprisingly, extension workers (18.3\%) whose mandate is to communicate to farmers new technology useful to them reach few farmers. Therefore, there is need for e-extension to prepare extension workers for e-transactions in respect of their clientele. The use of internet (21.7\%) as source of information was not popular in the zone even though it can enable the remotest village to access regular and reliable information from a global library (the web) (Ozor and Madukwe,2009). 
TABLE 1: Percentage distribution of respondents on sources of information on the use of ATMs

\begin{tabular}{lc}
\hline Information sources & Percentage $(\%)(\mathbf{n}=\mathbf{6 0})$ \\
\hline Television & 58.3 \\
Radio & 61.7 \\
Newspaper & 43.3 \\
Bank personnel & 80.0 \\
Friends and neighbours & 75.0 \\
Family members & 73.3 \\
Internet & 21.7 \\
Extension workers & 18.3 \\
Co-farmers & 38.3 \\
Co-operative society & 33.3 \\
Posters & 26.7 \\
Bulletin & 25.0 \\
Leaflet & 23.3 \\
Books & 40.0 \\
Email & 20.0 \\
Video player & 10.0 \\
Cinemas & 10.0 \\
Magazine & 25.0 \\
Churches & 23.3 \\
Schools & 36.7 \\
Media Van & 11.7 \\
\hline
\end{tabular}

Source: Field data, 2010

\section{Level of awareness on the use of ATMs}

The results in Table 2 show that the respondents had high level of awareness on the bank account (95.0\%), withdrawal booklet $(91.7 \%)$, ATM $(91.7 \%)$ and ATM card (81.7). But the respondents however exhibited low level of awareness on ATM cash dispenser (20.0\%) and ATM function keys $(41.7 \%)$. According to Chang and Cheung (2001), complexity also has significant relationship with the intention to use ATMs. He suggests the need for education of ATM users so as to update their knowledge and arouse their interest in all aspects of ATMs.

Furthermore, in terms of level of awareness of ATM (91.7\%), this finding is similar to that of Omankhanlen (2007) which stated that among the modern banking services such as electronic banking, internet banking, point of sales (POS) transactions, money transfer etc, ATMs emerged as the most popular with $96 \%$ awareness level. 
TABLE 2: Percentage distribution of respondents on their level of awareness of ATMs

\begin{tabular}{lc}
\hline ATM items $^{*}$ & Percentage $(\%)(\mathbf{n}=60)$ \\
\hline Bank account & 95.0 \\
Withdrawal booklet & 91.7 \\
ATM & 91.7 \\
ATM card & 81.7 \\
PIN & 61.7 \\
Benefits of using ATMs & 61.7 \\
Demerits of using ATMs & 51.7 \\
ATM operating hours & 40.0 \\
ATM locations & 60.0 \\
ATM display & 45.0 \\
ATM Function keys & 41.7 \\
ATM cash dispenser & 20.0 \\
Where ATM card is inserted & 41.7 \\
\hline
\end{tabular}

Source: Field data, 2010

\section{Level of use of ATMs}

The respondents exhibited high level of use of ATMs only in cash withdrawals $(55.0 \%)$. They had low level of use for other transactions like balance enquiries $(46.7 \%)$, transfer of funds (16.7\%), printing of mini statements and account statements (25.0\%), paying bills/fees/taxes (15.0\%) (Table 3). This is so because most Nigerians use ATM only for cash withdrawal. Although ATM machines can perform other functions and bills payment, cash withdrawal and balance enquiry remain the most popular applications sought after by users (Naija techguide, 2009).

This view was upheld by Fasan (2007) when he states that despite the rapid growth in the availability and use of ATMs, they remain a minor part of withdrawal of cash to farmers in their activities. The low level of use of the ATM in the zone resulted in abandonment of other transactions like transfer of funds, paying of bills, printing of bank statements which could have saved farmers' time. The implication is that time bound farm activities are adversely affected which can eventually lead to low agricultural productivity. However this finding (low level of use of ATMs) agrees with Hone, Graham, Magaire, Baber, and Johnson (1998) who states that in spite of the success and wide spread use of ATMs, a significant proportion of bank customers could not or would not use them or experience difficulties in their interactions. Given that individuals have already established personal banking norms, lifestyle, finance management system, and account monitoring mechanism prior to the advent of ATM, their acceptance or rejection of the technology will rely greatly on the extent to which it accommodates or rejects all or some of these past values. However, Blackwell, Engle and Miniard (1995) 
support previous studies that modern systems accept and adapt to innovation faster and easier than traditional systems.

TABLE 3: Percentage distribution of respondents on their level of use of ATMs

\begin{tabular}{lc}
\hline Transactions done with ATMs * & Percentage $\mathbf{( n = 6 0 )}$ \\
\hline Cash withdrawal & 55.0 \\
Transfer of funds & 16.7 \\
Balance enquires & 46.7 \\
Printing of mini statement and account statement & 25.0 \\
Recharging cell phones & 26.7 \\
Paying bills/fees/taxes & 15.0 \\
Cheque processing module & 1.6 \\
Updating pass book & 8.3 \\
Deposit currency recognition, & 1.6 \\
Purchasing & 6.7 \\
Donating charities & 3.3 \\
Exchange rate & 3.3 \\
\hline
\end{tabular}

Source: Field data, 2010

\section{Constraints on the use of ATM}

Some of the constraints in descending order of seriousness included: fraud $(M=1.65)$, debit without payment $(M=1.40)$, insecurity $(M=1.23)$, bank charges on the use of ATM $(M=1.22)$, network problems $(M=1.22)$, telecom breakdown $(\mathrm{M}=1.10)$, and uneven distribution of ATM $(\mathrm{M}=1.10)$ (Table 4). Farmers' constraints were mainly in the direction of cash withdrawals which was their major reason for patronizing ATM. On the contrary, it was observed that lack of necessary skills on the use of ATMs ( $M=0.87)$, complexity of the use of ATMs $(\mathrm{M}=0.90)$ and lack of knowledge of the use of ATMs (0.92) were not serious constraints. However, these aspects of the constraints need further education of customers (farmers) to enhance the use of ATMs. Other constraints not considered as serious included improper money checking $(M=0.48)$, poor maintenance of the ATMs by the bank $(M=0.65)$, long queue $(M=0.75)$ and card misplacement $(M=0.77)$. Based on this finding, one can say that ATMs have come to stay because a level of confidence has been placed in its use in spite of the obvious constraints. The results of standard deviation of the constraints revealed that they were true reflections of the situation in the entire population. 
TABLE 4: Mean score distribution of constraints on the use of ATMs

\begin{tabular}{|c|c|c|c|}
\hline Constraints & Mean (M) & $\begin{array}{c}\text { Standard } \\
\text { Deviation (SD) }\end{array}$ & Ranking \\
\hline Fraud & 1.65 & 0.709 & $1 \mathrm{st}$ \\
\hline Debit without payment & 1.40 & 0.718 & 2nd \\
\hline Insecurity & 1.23 & 0.621 & $3 r d$ \\
\hline Network Problem & 1.22 & 0.640 & 4th \\
\hline $\begin{array}{l}\text { Bank charges on the use of } \\
\text { ATMs }\end{array}$ & 1.22 & 0.613 & 4th \\
\hline Telecom breakdown & 1.10 & 0.706 & 6th \\
\hline Uneven distribution of the ATMs & 1.10 & 0.706 & 6th \\
\hline $\begin{array}{l}\text { No brochures for direction on } \\
\text { how to use the ATMs }\end{array}$ & 1.08 & 0.766 & 8th \\
\hline Limited access to ATMs & 1.07 & 0.660 & 9th \\
\hline Poor sight & 1.05 & 0.910 & 10th \\
\hline Power outage & 0.98 & 0.676 & 11th \\
\hline $\begin{array}{l}\text { Unable to dispense cash when } \\
\text { the card is slotted in }\end{array}$ & 0.97 & 0.688 & 12th \\
\hline $\begin{array}{l}\text { Lack of Knowledge of the use of } \\
\text { ATMs }\end{array}$ & 0.92 & 0.671 & 13th \\
\hline Complexity of the use of ATMs & 0.90 & 0.681 & 14th \\
\hline $\begin{array}{l}\text { Lack of necessary skills on the } \\
\text { use of ATMs }\end{array}$ & 0.87 & 0.700 & 15th \\
\hline $\begin{array}{l}\text { Lack of confidence in operating } \\
\text { ATMs }\end{array}$ & 0.83 & 0.587 & 16th \\
\hline Inadequacy of the machines & 0.80 & 0.819 & 17th \\
\hline Card misplacement & 0.77 & 0.698 & 18th \\
\hline Long queue & 0.75 & 0.704 & 19th \\
\hline $\begin{array}{l}\text { Negative thoughts of the people } \\
\text { on ATMs use }\end{array}$ & 0.73 & 0.710 & 20th \\
\hline $\begin{array}{l}\text { Poor maintenance of the ATMs } \\
\text { by the bankers }\end{array}$ & 0.65 & 0.732 & $21 \mathrm{st}$ \\
\hline Improper money checking & 0.48 & 0.624 & 22nd \\
\hline Age barrier & 0.38 & 0.524 & 23rd \\
\hline
\end{tabular}

Source: Field data, 2010

\section{Perceived benefits from the use of ATMs}

Out of the twenty six (26) possible benefits listed in Table 5, 16 were considered important benefits to users of ATM. They included time saving $(M=2.85)$, cash withdrawal $(M=2.70)$, easy access $(M=2.60)$, greater efficiency $(M=2.45)$, convenience $(M=2.23)$, etc. This implies that farmers who patronize ATMs can meet up with their time bound agricultural activities conveniently. The use of ATMs appeared to provide convenience $(M=2.23)$ compared with using the teller in the banking hall. It was also evident that the respondents perceived easy access ( $M=2.60)$ to information as important benefit derived from the use of ATMs. 
According to Ozor and Madukwe (2009), information communication technologies (ICTs) are known to offer new approaches towards agricultural development. The promise of ICT in agricultural development is that it can energize the collection, processing and transmission of data resulting in faster extension of quality information to more farmers in a bottom-up and interactive means of communication. The implication is that farmers can easily acquire new agricultural technologies for improved yield and consequent rise in their standard of living. On the contrary, the respondents perceived security $(M=1.45)$ as less important benefit in the use of ATMs. This is likely to affect the adoption of the technology because of the risk involved. According to Sheth (1981), proposition that lowered perceived risk increases the likelihood of consumer adoption and the opposite is true. Again, the respondents did not perceive the following as important benefits of using ATMs: transfer of funds $(M=1.45)$, exchange rate $(M=0.93)$, exchange rate $(\mathrm{M}=0.93)$ etc.

\section{TABLE 5: Perceived benefits from the use of ATMs}

\begin{tabular}{lcc}
\hline \multicolumn{1}{c}{ Benefits } & Mean(M) & Standard Deviation (SD) \\
\hline Time saving & 2.85 & 0.515 \\
Control & 2.02 & 0.965 \\
Security & 1.45 & 0.723 \\
Easy access & 2.60 & 0.588 \\
Reduced operating cost & 1.62 & 0.904 \\
Greater efficiency & 2.45 & 0.832 \\
Transfer of funds & 1.45 & 0.872 \\
Balance enquiries & 2.15 & 0.755 \\
Printing of mini statements and account & 1.80 & 0.840 \\
statements & & \\
Cash withdrawal & 2.70 & 0.646 \\
Exchange rate & 0.93 & 0.800 \\
Deposit currency recognition, acceptance & 0.75 & 0.914 \\
and recycling & & \\
Paying routine bills, fees and taxes & 0.85 & 0.988 \\
Updating passbooks & 0.75 & 0.914 \\
Loading monetary values & 0.68 & 0.854 \\
Purchasing & 0.70 & 0.926 \\
Cheque processing module & 0.72 & 0.940 \\
Adding prepaid cell phone credit & 1.28 & 0.940 \\
Facilitates decision making & 1.60 & 0.764 \\
Facilitate problem solving & 1.75 & 0.876 \\
Help farmers learn about new technologies & 2.05 & 0.852 \\
of banking faster & & \\
Facilitate rural development & 2.50 & 0.651 \\
Help empower rural people & 2.45 & 0.723 \\
Enhance income earnings & 1.20 & 0.798 \\
Provide convenience & 2.23 & 0.621 \\
Provide high speed communication & 1.25 & 0.895 \\
\hline Source: Field data, 2010 & &
\end{tabular}

Source: Field data, 2010 


\section{CONCLUSION AND RECOMMENDATIONS}

Based on the findings of the study, it was concluded that majority of farmers were aware of bank account (95.02\%), withdrawal booklet (91.7\%), ATM $(91.7 \%)$ and ATM card (81.7) but exhibited low awareness on ATM cash dispenser $(20.0 \%)$ and ATM function key $(41.7 \%)$. The farmers' main sources of information were bank personnel, friends and neighbours, family members, radio and television. The use of ATMs was generally low consisting mainly of cash withdrawals. Some of the important benefits of the use of ATMs were time saving, cash withdrawals and easy access while serious constraints were fraud, bank charges on the use of ATMs, network problems, telecom breakdown and insecurity.

The study recommended mounting of awareness campaign on the use of ATMs by banks through workshop, seminars, conferences, and meetings with farmers' group. The banking system should also look into the charges fixed on the use of ATMs by farmers and also deploy specially trained security guards as well as mount multiple security cameras to reduce fraud.

\section{REFERENCES}

Blackwell, R. D., Engle, J. F. and Miniard, P. W. (1995). Diffusion of Innovation in Consumer Behaviour. London: Dryden Press.

Chang, M. K., and Cheung, W. (2001). Determinants of the intention to use internet/www at work: A confirmatory study. Information and Management, 39(1): 1-14.

Fasan, R. (2007). Banks, customer relation and use of ATM cards. Business Day Newspaper, retrieved February 28, 2008.

(http://www.businessdayonline.com)

Hone, K.S., Graham R., Magaire M.C., Baber C. and Johnson G. (1998). Spech technology for Automatic Teller Machines: an Investigation of user attitude and performance. Ergonomics, 41 (7): 96-98.

Naija Techguide (2009) http://naijatechguide.blogspot.com/2009/05/web-hostingoverview.html. electronic payment/transactions in Nigeria.

Olatakun W. C. and Igbinedion L.J. (2009). The adoption of ATMs in Nigeria: an application of the theory of diffusion of innovation. Issues in Informing Science and Technology, vol. 6, 2009.

Okoye C. U. (1995). The rural economy and community banking in Nigeria. In Eboh, E. C., Okoye, C. U. and Ayichi, D. (Eds.), Rural Development in Nigeria: Concepts, Processes and Prospects. Auto-Century Publishers Company Limited: 200-215.

Omankhanlen, O. (2007). ATM rising threat and users dilemma. Retried January 16, 2008 from http://www.tribune.com.ng. 
Ozor, N. and Madukwe, M. C. (2009). Role of information communication technology (ICT) in Agricultural Development. In: B.C. Echezona (ed.). General Agriculture:Principles and Practices. Faculty of Agriculture, University of Nigeria, Nsukka. University of Nigeria Press Ltd: 20-24.

Sheth, J. N. (1981). Psychology of innovation resistance: the less developed concept (LDC) in diffusion research. Research in Marketing, 4: 273-282.

Ugwu, E. (2008). CBN bank to tackle ATMs hitches. Retrieved April 18, 2008 (http://www.guardiannewsngr.com). 